Bull. Fac.Agric., Cairo Univ. 64:46-58 (2013)

\title{
ADAPTATION AND SELECTION FOR NEW SALINITY TOLERATING \\ TOMATO LINE (Lycopersicon esculentum)
}

(Received:19.11.2012)

\author{
By \\ H.H. Hamed and S.M. Ahmed \\ Horticulture Research Institute, Agriculture Research Center, Giza, Egypt
}

\begin{abstract}
This study aimed to investigate the adaptation and selection of Castle Rock (fresh market tomato cv) for salinity tolerance. Also, to study the initial assessment of epigenetic variation under the salinity stress and taking advantage of these variations to adapt and select new tolerant line of Castle Rock. The study took about 6 years from 2005 to 2010. Adaptation and selection was conducted for the characteristics, plant height, main stem diameter, number of branches per plant, number of leaves per plant, leaf area, dry matters weight per plant, fruit setting, number of days to $50 \%$ flowering, number of days to fruit ripening, number of fruits per plant, average fruit weight, total yield per plant, total chlorophyll content, total soluble solids, titrated acidity, vitamin $\mathrm{C}$ content, seed germination, proline content, $\mathrm{Ca}^{++}, \mathrm{K}^{+}$and $\mathrm{Na}^{+}$ content. As well as, anatomy was done for the main stem examining the percentage in measure between the stem diameter and pith, cortex and xylem. Three tomato genotypes were under the trial, Castle Rock (salinity sensitive cv), Edkawy (salinity tolerance cv) and $\mathrm{C}_{9}$ (Castle Rock adapted selected new line). $\mathrm{C}_{9}$ proved tolerant to salinity through adaptation in 9 selecting cycles and it can be reproduced as a new Castle Rock improved line for salinity tolerance.
\end{abstract}

Key words: adaptation and selection, salinity tolerance, tomato.

\section{INTRODUCTION}

Stalinization plays a major role in soil degradation. It affects $19.5 \%$ of irrigated land and $2.1 \%$ of dry land agriculture existing on the globe. In many crop production areas., using of low quality water for irrigation and application of excess amounts of mineral fertilizers are the major reasons for increasing salinity problem in cultivated soils. Due to very rapid accumulation of salts in soil, salinity problem is also a critical constraint to vegetable production (Shannon and Grieve, 1999). Salinity effects are more conspicuous in arid and semiarid regions, where limited rainfall, high evaporation and high temperature associated with poor water soil management contribute to the salinity problem and become of great importance for agriculture production in these regions.

Environment cues are perceived and transmitted by a myriad of plant signal transduction pathways that, by turning on specific transcription factors in the nucleus, lead to the activation of genes encoding effectors productions that enable adaptation to environmental challenges. In recent years, it is become clear that dynamic changes in chromatin properties and the biogenesis of small RNAs also contribute to transcriptional and posttranscriptional regulation of gene expression important for stress responses (Angers et al., 2010; Madlung and Comai, 2004; Borsani et al., 2005; and Kumar \& Wigge, 2010). Salt tolerance is a complex, quantitative, genetic character controlled by many genes. A few of these genes have been identified and provide information that can be useful in screening and selection programs (Shannon and Noble, 1990). Information is lacking on how most genes function in concert with other genes that may have influenced the mechanisms of salt tolerance. There is some capacity for selection under a particular stress environment, i.e., genetic variance is high compared to that under non-stress, tolerance might be improved without a concomitant yield decrease in a non-stress environment. These principles were demonstrated by Johnson et al. (1992) who found that selection for increased yield in alfalfa was effective under low and moderate salinities but not under non-saline conditions. Selection for salt 
tolerance under the wrong conditions or using the wrong genetic material can result in low yielding selections that are not competitive with higher yielding, non-tolerant varieties (Richard, 1983). Environmentally induced epigenetic status (studying of heritable changes that occur without a change in the DNA sequence) thus could be passed to the progeny. Plant epigenetic has recently gained unprecedented interest, not only as a subject of basic research but also as possible new source of beneficial traits for plant breeding. These mechanisms are responsible for the formation of heritable epigenetic gene variants (epialleles) and also regulate transposons (a segment of DNA that is capable of independintally replicating itself and inserting the copy into a new position within the same or another chromosome or plasmid) mobility, both aspects could be exploited to broaden plant phenotypic and genetic variation, which could improve long-term plant adaptation to environmental challenges and, thus, increase productivity (Mirouze and Paszkowski, 2011). The main target of this investigation aimed to study the initial assessment of the degree of hidden epigenetic variation under stress conditions among genetically broad-based variety (Castle Rock), and then take advantage of these variations to obtain that breed salinity-tolerant.

\section{MATERIALS AND METHODS}

The current study was conducted during the years of 2005 to 2010. Two tomato cultivars, Castle Rock (salinity sensitive) and Edkawy (salinitiy tolerant), were used in an adaptation trial for Castle Rock cv to adapt and select new tolerant genotype. Nine selected adapted generations were achieved in plastic pots in two growing times, mid of February and August, during 2005 to 2009 for the adaptation trial in glasshouse at Vegetable Research Departments, Dokki-Giza and the evaluation trial for the ninth generation was carried out in plastic bags on Summer (mid of February) 2010 in the open field at Kaha Vegetable Research Station, Kalubia Governorate. The adaptation treatment was applied by diluting the sea water at the ratio 1 (sea water): 5 (fresh water) which measured 7.86 EC. Table (1) shows the Chemical analysis for water samples used in the trial. The plants during the adaptation trial were irrigated two times by saline water without fertilizers and followed by one time by fresh water with compound fertilizer (Kristalon: 19 -19 -19, 1 $\mathrm{gm} /$ Liter). The evaluating trial was achieved for Castle Rock cv (mother population) and Edkawy (tolerated $\mathrm{cv}$ ) that were irrigated with fresh water and saline water, while Castle Rock (adapted selected population, $\mathrm{C}_{9}$ ) was irrigated with saline water. The used saline water for the evaluating trial was a diluted sea water for 4 EC (4 deciSemiens per meter $=4 \mathrm{dsm}^{-1}=4$ milliohms per centimeter $=4^{*} 640 \mathrm{ppm}$ ) that was applied during the whole trial period as alternately with irrigation contained compound fertilizer (Kristalon, $1 \mathrm{~g} /$ Liter). The used plastic pots and bags in both adaptation and evaluation trials were 20 liters volume and contained washed sandy soil with chicken manure.

\section{Plant evaluation}

Data were recorded for the characteristics, plant height $(\mathrm{cm})$, main stem diameter $(\mathrm{cm})$, number of branches per plant, number of leaves per plant, leaf area $\left(\mathrm{cm}^{2}\right)$, dry matter content per plant (g), fruit setting (\%), number of days to $50 \%$ flowering, number of days to fruit ripening, number of fruit per plant, average fruit weight $(\mathrm{g})$, total yield per plant $(\mathrm{g})$, total chlorophyll content (SPAD units), total soluble solids per plant (\%), titrated acidity (TA), vitamin $\mathrm{C}$ content (mg/100g), seed germination (\%), proline content (mmol $\left.\mathrm{kg}^{-1} \mathrm{FW}\right), \mathrm{Ca}^{++}$content (mg/plant) samples of leaves were taken three weeks later.

The determination of nutrient concentrations were according to Chapman and Pratt (1978). $\mathrm{K}^{+}$ content (mg/plant), $\mathrm{Na}^{+}$content (mg/plant) and the anatomy of main stem was done to examine the differences between the diameter of cortex and pith comparing to the diameter of main stem, determination of the differences between the diameter of pith to the diameter of cortex. In addition, comparing the diameter of xylem vessels to the diameter of parenchyma cells of xylem. The three genotypes namely Castle Rock (sensitive genotype - mother population), Edkawy (tolerated genotype) and Castle Rock (adapted selected population $-\mathrm{C}_{9}$ ) were used to an anatomy of main stem.

The Randomized Complete Block design (RCB) statistical analysis according to Snedecor and Cochran (1980) with three replications was used while the differences among the treatment means were compared using Duncan's (1955) multiple range test at 5\% level.

Estimation of proline content in leaves was determined as described by Bates et al. (1973). Leaf tissues $(250 \mathrm{mg})$ were rinsed three times with distilled water and the stoppered tubes with $10 \mathrm{ml}$ water placed in a boiling water for $10 \mathrm{~min}$ to extract the hot water - soluble compounds. An aliquot of water extract was treated with ninhydrin reagent. Toluene phase was decanted and the 
Table (1): Chemical characterization of water used for irrigation.

\begin{tabular}{|c|c|c|c|c|c|c|c|c|}
\hline \multirow{2}{*}{$\operatorname{EC}\left(\mathrm{ds} \mathrm{m}^{-1}\right)$} & \multirow{2}{*}{ pH } & \multicolumn{6}{|c|}{ Soluble ions (meq I ${ }^{-1}$ ) } & \multirow{2}{*}{ SAR } \\
\hline & & $\mathrm{Ca}^{++}+\mathrm{Mg}^{++}$ & $\mathrm{Na}^{+}$ & $\mathbf{K}^{+}$ & $\mathrm{HCO3}^{-}$ & $\mathrm{Cl}^{-}$ & SO4-- $^{-1}$ & \\
\hline Fresh water: 0.43 & 7.05 & 3.85 & 0.73 & 0.16 & 1.53 & 1.92 & 1.29 & 0.53 \\
\hline Diluted sea water: 4 & 7.27 & 17.49 & 25.3 & 0.42 & 1.21 & 39.47 & 2.53 & 8.55 \\
\hline Diluted sea water (1:5): 7.86 & 7.63 & 39.35 & 61.2 & 0.60 & 1.73 & 78.65 & 20.77 & 13.78 \\
\hline
\end{tabular}

absorbance was recorded at $250 \mathrm{~nm}$. The concentration of proline was calculated from a standard curve plotted with known concentration of L-proline as standard.

Estimation of vitamin $\mathrm{C}$, total soluble solids (TSS) and titrated acidity: Three tomato fruits were juiced to be used in analysis of total soluble solids, vitamin $\mathrm{C}$ and titratable acidity. Total soluble solids content was measured with an optical refractometer. Titratable acidity was determined by titration with $0.1 \mathrm{M} \mathrm{NaOH}$, also vitamin $\mathrm{C}$ content was determined according to A.O.A.C (1980). Chlorophyll content was measured with a SPAD.

\section{RESULTS AND DISCUSSION}

Data in Table (2) show the mean values of mother population of sensitive tomato plants (Castle Rock cv) and the selected individual plants that were derived from mother population for the yield character. The obtained results clearly showed that there were increasing in selection response to salinity adaptation in yield. The mother population $(43.97 \mathrm{~g})$ and the selected individual derived from mother population 102.90 $\left(C_{0}\right)$ were lower in yield than the selected ninth cycle plants through adaptation to salinity and the individual selected plants $\left(\mathrm{C}_{9}\right), 99.51 \mathrm{~g}$ and 260.82 $\mathrm{g}$, respectively. The increasing in the mean values was gradually through the selecting cycles from the first to the ninth cycle and that was in agreement with the breeder target during the study.

While, the coefficient of variation (CV\%) showed reduction in respect to the yield of mother population, $72.30 \%\left(\mathrm{C}_{0}\right)$ than the single selected plant, $41.30 \%\left(\mathrm{C}_{9}\right)$. That reduction was gradually through the nine selecting cycles from the first to the ninth cycle and that was in agreement with the breeder target. Our finding generally agreed with those of Dai et al. (2007), Deal and Henikoff (2010) and Mirouze and Paszkowski (2011), who reported that there are many examples of acquired traits related to the activities of transposons, and especially retroelements, which are an abundant component of plant genomes. Thus, we propose that the most attractive way by which epigenetic regulation could contribute to enrichment of novel traits related to plant stress adaptation is, directly or indirectly, the controlled generation and exploitation of retrotransposon (transposon copied from RNA with the use of reverse transcriptase) induced genetic diversity. We could even envisage that plant populations with a variety of new retroelement insertions, to recruit activated retrotransposons as fast drivers of evolution. Nextgeneration sequencing technologies, the availability of methylomes from plants responding to stress, and access to tissue-specific or single cell-specific genome and epigenome information may provide us with sufficient resolution power and, thereby, more dynamic and thus more complete appreciation of the mobile part of the genome, mobilome. This will shed new light on its role in adaptive plant responses and their evolution.

Table (3a) shows the mean square for analysis of variance of genotypes (Castle Rock mother population-sensitive genotype, Edkawy tolerant genotype and Castle Rock adapted selected population) of tomato grown under saline irrigation. The results show significant differences for the characteristics: plant height, main stem diameter, number of branches per plant, number of leaves per plant, leaf area, dry matter per plant and fruit setting. Data in Table (3b) showed the mean values of plant performance and the reduction and increasing percentage compared to the Castle Rock (mother population) for the characteristics plant height, main stem diameter, number of branches per plant, number of leaves per plant, leaf area, dry matter weight per plant and fruit setting difference percentage. The results showed that there was a significant for all previously mentioned characteristics. Regarding the mean values, there was significant differences for all the treatments between the adapted selected population compared to the mother population and Edkawy for all the characteristics except for number of branches per plant and fruit setting of the adapted selected population compared to Edkawy in saline water treatment that showed no significant differences. Also, the adapted selected population compared to the mother population under saline water irrigation showed no significant differences for the characteristic number of leaves per plant. The 
H.H. Hamed and S.M. Ahmed.

Table (2): Selecting cycles for tomato plants (Castle Rock variety) under saline water irrigation during the years 2005 to 2009.

\begin{tabular}{|c|c|c|c|c|c|c|}
\hline \multirow[b]{2}{*}{$\begin{array}{l}\text { Selecting } \\
\text { cycles }\end{array}$} & \multirow{2}{*}{$\begin{array}{c}\text { Number of } \\
\text { population } \\
\text { plants (n) }\end{array}$} & \multirow{2}{*}{$\begin{array}{l}\text { Average } \\
\text { yield (g } \\
\left.\text { plant }^{-1}\right)\end{array}$} & \multirow{2}{*}{$\begin{array}{c}\text { Number of } \\
\text { survival } \\
\text { plants }\end{array}$} & \multirow{2}{*}{$\begin{array}{c}\text { Coefficient } \\
\text { variance } \\
(\mathrm{CV} \%)\end{array}$} & \multicolumn{2}{|c|}{ Selected plants } \\
\hline & & & & & $\begin{array}{c}\text { Individual } \\
\text { plant yield } \\
\text { (g) }\end{array}$ & Entry code \\
\hline \multirow{4}{*}{$\begin{array}{c}\mathbf{C}_{0} \\
\text { (mother } \\
\text { population) } \\
\text { (Summer } \\
\text { 2005) }\end{array}$} & \multirow{4}{*}{120} & \multirow{4}{*}{43.97} & \multirow{4}{*}{71} & \multirow{4}{*}{72.30} & 104.21 & CR-C0-1 \\
\hline & & & & & 103.15 & CR-C0-2 \\
\hline & & & & & 101.35 & $\mathrm{CR}-\mathrm{C} 0-3$ \\
\hline & & & & & 102.90 & Mean \\
\hline \multirow{4}{*}{$\begin{array}{c}\mathrm{C}_{1} \\
\text { (Fall 2005) }\end{array}$} & \multirow{4}{*}{120} & \multirow{4}{*}{42.34} & \multirow{4}{*}{69} & \multirow{4}{*}{70.90} & 122.53 & CR-C1-1 \\
\hline & & & & & 120.31 & CR-C1-2 \\
\hline & & & & & 119.25 & CR-C1-3 \\
\hline & & & & & 120.70 & Mean \\
\hline \multirow{4}{*}{$\begin{array}{c}\mathrm{C}_{2} \\
(\mathrm{Summer} \\
2006)\end{array}$} & \multirow{4}{*}{120} & \multirow{4}{*}{50.67} & \multirow{4}{*}{75} & \multirow{4}{*}{64.50} & 155.73 & CR-C2-1 \\
\hline & & & & & 150.65 & CR-C2-2 \\
\hline & & & & & 145.93 & CR-C2-3 \\
\hline & & & & & 150.77 & Mean \\
\hline \multirow{4}{*}{$\begin{array}{c}\mathrm{C}_{3} \\
\text { (Fall 2006) }\end{array}$} & \multirow{4}{*}{120} & \multirow{4}{*}{59.23} & \multirow{4}{*}{77} & & 173.56 & CR-C3-1 \\
\hline & & & & & 169.59 & CR-C3-2 \\
\hline & & & & 55.30 & 162.62 & CR-C3-3 \\
\hline & & & & & 168.59 & Mean \\
\hline $\mathrm{C}_{4}$ & & & & & 189.53 & CR-C4-1 \\
\hline & & & & & 189.97 & CR-C4-2 \\
\hline (Summer & 120 & 59.23 & 74 & 55.90 & 186.31 & CR-C4-3 \\
\hline & & & & & 187.60 & Mean \\
\hline & & & & & 203.51 & CR-C5-1 \\
\hline & & & & & 201.73 & CR-C5-2 \\
\hline (Fall 2007) & 120 & 73.55 & 71 & 49.70 & 188.59 & CR-C5-3 \\
\hline & & & & & 197.94 & Mean \\
\hline $\mathrm{C}_{6}$ & & & & & 223.51 & CR-C6-1 \\
\hline$\sigma_{0}$ & & & & & 220.15 & CR-C6-2 \\
\hline (Summer & 120 & 73.92 & 76 & 49.30 & 211.63 & CR-C6-3 \\
\hline & & & & & 218.43 & Mean \\
\hline & & & & & 230.51 & CR-C7-1 \\
\hline & & & & & 226.43 & CR-C7-2 \\
\hline & 120 & 89.23 & 75 & 44.40 & 221.13 & CR-C7-3 \\
\hline & & & & & 226.02 & Mean \\
\hline $\mathrm{C}_{8}$ & & & & & 264.63 & CR-C8-1 \\
\hline & & & & & 261.52 & CR-C8-2 \\
\hline (Summer & 120 & 95.52 & 79 & 40.20 & 254.13 & CR-C8-3 \\
\hline & & & & & 260.09 & Mean \\
\hline & & & & & 271.13 & CR-C9-1 \\
\hline (Fall 2009) & & & & & 262.21 & CR-C9-2 \\
\hline adapted & 120 & 99.51 & 77 & 41.30 & 249.13 & CR-C9-3 \\
\hline $\begin{array}{c}\text { selected } \\
\text { population }\end{array}$ & & & & & 260.82 & Mean \\
\hline
\end{tabular}

adapted selected population compared to the mother population showed reduction under fresh water treatment characteristics, plant height (-
15.40), main stem diameter (-9.69), leaf area ($3.80)$, dry matter weight per plant $(-10.35)$ and fruit setting (-5.19), while it showed increasing 
under the same treatment in two characteristics namely number of branches per plant (45.68) and number of leaves per plant (0.73). In addition, it showed increasing for the characteristics: plant height (83.41), main stem diameter (17.46), number of branches per plant (77.59), number of leaves per plant (51.67), leaf area (31.64), dry matter weight (32.92) and fruit setting (39.87) under saline water irrigation.

Table (4a) shows the mean square for analysis of variance of genotypes (Castle Rock mother population-sensitive genotype, Edkawy tolerant genotype and Castle Rock adapted selected population) of tomato grown under saline irrigation. The results show significant differences for the characteristics number of days to $50 \%$ flowering, number of days to fruit ripening, number of fruits per plant, average fruit weight, total yield per plant, total chlorophyll content and total soluble solids. Data in Table (4b) showed the mean values of Castle Rock (mother population), Edkawy and the Castle Rock (adapted selected population), beside the reduction and increasing in the adapted selected population compared to Castle Rock (mother population) for the characteristics, number of days to $50 \%$ flowering, number of days to fruit ripening, number of days to fruit ripening, number of fruits per plant, average fruit weight, total yield per plant, total chlorophyll content and total soluble solids. The results showed significant differences for all characteristics. In respect to the differences among the mean performances there was a significant difference under both fresh and saline water irrigation comparing the adapted selected population to the mother population and Edkawy for the characteristics, number of days to fruit ripening, average fruit weight, total yield per plant, total chlorophyll content and total soluble solids. While, under the saline water irrigation there was no significant differences among the mean values of the Castle Rock (adopted selected population) comparing to both Castle Rock (mother population) and Edkawy for the characteristics number of days to $50 \%$ flowering and number of fruits per plant.

Comparing the Castle Rock (adapted selected population) to the Castle Rock (mother population) under fresh water irrigation, it showed reduction in mean performance for the characteristics number of days to ripening (-8.95), number of fruits per plant $(-11.10)$, average fruit weight (-8.18), total yield per plant $(-17.80)$, total chlorophyll content $(-14,20)$ and under saline water irrigation for number of days to $50 \%$ flowering (-21.27), total soluble solids (-30.18). On the other hand, the adapted selected population showed increasing compared to the mother population (fresh water) for the characteristics number of days to $50 \%$ flowering (10.22) and total soluble solids (9.88), and the mother population (saline water) for number of days to fruit ripening (31.51), number of fruits per plant (1.34), average fruit weight (81.89), total yield per plant (68.95) and total chlorophyll content (24.16).

Table (5a) shows the mean square for analysis of variance of genotypes (Castle Rock mother population-sensitive genotype, Edkawy tolerant genotype and Castle Rock adapted selected population) of tomato grown under saline irrigation. The results show significant differences for the characteristics titrated acidity, vitamin C content, seed germination, proline content, $\mathrm{Ca}, \mathrm{K}$ and $\mathrm{Na}$ content. Data in Table (5b) showed the mean plant performance of Castle Rock (mother population) and Edkawy under both fresh and saline water besides the Castle Rock (adapted selected population) under saline water, also it showed the reduction and increasing in the adapted selected population $\left(\mathrm{C}_{9}\right)$ compared to the mother population (Castle Rock cv). The results obviously showed significant differences for the characteristics, titrated acidity, vitamin $\mathrm{C}$ content, seed germination, seed germination percentage, proline content, $\mathrm{Ca}^{++}$content, $\mathrm{K}^{+}$content and $\mathrm{Na}^{+}$ content. The compared means between Castle Rock (adapted selected population $\mathrm{C}_{9}$ ), Castle Rock (mother population) and Edkawy showed significant differences for the characteristic shown in Table (5b) except for the vitamin C content and $\mathrm{Na}^{+}$content in comparing the adapted selected population $\left(\mathrm{C}_{9}\right.$ - saline water) to the mother population (fresh water). In respect to the reduction and increasing in mean plant performances, the Castle Rock (adapted selected population $\mathrm{C}_{9}$ ) compared to the Castle Rock (mother population - fresh water irrigation) showed reduction for seed germination $(-18.38)$, $\mathrm{Ca}^{+}$content (-8.17) and $\mathrm{K}^{+}$content $(-11.25)$, while it showed increasing for titrated acidity (3.57), vitamin C content (0.42), proline content (147.93) and $\mathrm{Na}^{+}$content $(2.88)$. On the other hand, Castle Rock (adapted selected population - $\mathrm{C}_{9}$ ) compared to the mother population (saline water irrigation) showed reduction in the mean performance of the characteristics titrated acidity (-13.66), vitamin C content (-1.05), proline content $(-9.57)$ and $\mathrm{Na}^{+}$ content (-82.40), while it showed increasing for seed germination (44.83), $\mathrm{Ca}^{++}$content (104.36) and $\mathrm{K}^{+}$content (95.96). Our findings generally 
agreed with that of Hsiao (1973) who reported that the higher salinity affects the osmotic pressure and the water absorption in plant which affects consequentially the cell division and the meristemic cells growth in apical myristime and prevent them of getting the adequate size that allow to divide, and in the meantime affects plant growth especially plant height. Also, RajaseKaran and Shanmugavelu (1981) reported reduction in plant height by increasing the salinity in water irrigation of tomato $(0.9-4.5$ deciSemiens per meter $\left(\mathrm{ds} \mathrm{m}^{-1}\right),\left(2.8 \mathrm{ds} \mathrm{m}^{-1}\right)$ and $\left(6.5 \mathrm{ds} \mathrm{m}^{-1}\right)$.

Many researchers mentioned the reduction in dry matter weight of tomato plants under higher salinity $\left(1.5,3,4.5,6,8\right.$ and $\left.10 \mathrm{ds} \mathrm{m}^{-1}\right)$, Skogley and Haider (1969) and Nanawati and Maliwal (1974). Francois and Bernstein (1964) stated that salinity in growth area causes the plants to flower fast and fruit ripening as well. While, Kazim (1978) reported the contrary that the higher salinity resulted in preventing and delaying the flowering in tomato plants. In addition, Mizrahi (1982) reported that salinity caused the tomato plants to decrease the period between fruit setting and fruit ripening as well as the fruits were smaller in size and better in taste.

Salinity affects plant yield where it reduces the fruit weight, number and seeds through affecting the plant vegetative growth and nutritional balance in plant (Lapina and Popov, 1970 and Hsiao, 1973). Also, Shalhevet and Yaron (1973) found that the reduction of yield was $10 \%$ for each $1.5 \mathrm{ds}$ $\mathrm{m}^{-1}$ higher salinity than in the root zone. In addition, Bernstein et al. (1974) reported that yield reduced by $50 \%$ under saline soil $\left(8 \mathrm{ds} \mathrm{m}^{-1}\right)$. Similar results were obtained by Nukaya et al. (1979) who reported that tomato was irrigated with saline water $(50-3000 \mathrm{ppm})$ the yield reduced by $47 \%$. Rajasekaran and Shanmugavelu (1981) and Mondal (1983) reported reduction in tomato yield that was grown under irrigation with saline water ranged from 2.8 to $10.2 \mathrm{ds} \mathrm{m}^{-1}$, the reduction ranged from 5 to $40 \%$.

Many other researchers emphasized that salinity affects the photosynthesis process through affecting the chlorophyll content where the higher salinity leads to changes in chloroplasts construction and reduction in chlorophyll content and consequentially reduction in photosynthesis process (Nieman, 1962). In addition, Sivtser et al. (1973) reported that the higher salinity causes suppression of enzyme constructing like chlorophyllase that responsible of chlorophyll in plants. Also, salinity leads to reduction in chlorophyll of the tomato leaves that could be due to the negatively affection on chloroplast constructing and suppressing the nutritional elements absorption and transporting. Also, Tsenov et al. (1973) mentioned that the higher salinity leads to suppress the DNA and RNA production in tomato plant. In addition, it affects in constructing of some enzymes and their function especially ATPase that plays important role in the active transporting of ions through blasmic membrane (Knight et al., 1997).

The amount of free proline is dependent on the degree of osmotic stress (Flowers et al., 1977). Under non-saline conditions proline levels are low and increase as the salinity is raised and the capacity of proline accumulations is correlated with tolerance (Stewart and Lee, 1974). Amino acid proline concentration is positively correlated with the amount of $\mathrm{Na}^{++} \mathrm{Cl}^{-}$in the plant. After a certain period, depending on plant age, the molar ratio of proline to $\left(\mathrm{Na}^{++} \mathrm{Cl}^{-}\right)$becomes constant. It is possible that proline may function as a compatible solute in the important role of balancing cytoplasmic and vacuolar water potentials (Flowers et al., 1977)

The maximum soil salinity level that is tolerated by tomatoes without yield reduction is $\mathrm{EC}_{\mathrm{e}}=2.5 \mathrm{ds} \mathrm{m}^{-1}$ (Maas and Hoffman, 1977). However, as salinity increases, fruit development time is shortened by $4-15 \%$ and fruit size and juice $\mathrm{pH}$ is reduced (Mizrahi, 1982). The later author also reported an increase in total soluble solids (TSS), titratable acidity (TA), reducing sugars, and electrical conductivity (EC) of the tomato juice subjected to 3 and 6 grams of $\mathrm{NaCl}$ per liter $\left(\mathrm{EC}_{\mathrm{w}}=4.7\right.$ and $\left.9.4 \mathrm{ds} \mathrm{m}^{-1}\right)$ of irrigation water.

Calcium ions play a crucial role in the regulation of the salt economy of plants and specially in the selective transport or exclusion of $\mathrm{Na}^{+}$and specifically in the selective transport or exclusion of $\mathrm{Na}^{+}$and other mineral ions by plant cell membrane (Lahaye and Epstein, 1969). Salinity reduces leaf $\mathrm{K}^{+}, \mathrm{Ca}^{++}, \mathrm{Mg}^{++}$and $\mathrm{NO}_{3}^{-}$ concentrations. Those plants which take up more $\mathrm{K}^{+}, \mathrm{Ca}^{++}, \mathrm{Mg}^{++}$and $\mathrm{NO}_{3}^{-}$from the medium will have lower $\mathrm{Na}^{+} / \mathrm{K}^{+}, \mathrm{Na}^{+} / \mathrm{Ca}^{++}$and $\mathrm{Na}^{+} / \mathrm{Mg}^{++}$ratios and an equilibrium of nutrients more similar to the non-Salinised plants (Cuartero et al., 1992; PerezAlfocea et al., 1996).

Table (6a) shows the mean square for analysis of variance of genotypes (Castle Rock mother population-sensitive genotype, Edkawy tolerant genotype and Castle Rock adapted selected population) of tomato grown under saline irrigation. The results show significant differences 
Table (3a): Mean square for analysis of variance of genotypes (Castle Rock mother population-sensitive genotype, Edkawy tolerant genotype and Castle Rock adapted selected population) of tomato grown under saline irrigation during the year 2010.

\begin{tabular}{|c|c|c|c|c|c|c|c|c|}
\hline \multirow[b]{2}{*}{ Source of Variance } & \multirow[b]{2}{*}{ DF } & \multicolumn{7}{|c|}{ Characteristics } \\
\hline & & $\begin{array}{c}\text { Plant height } \\
(\mathrm{cm})\end{array}$ & $\begin{array}{l}\text { Main stem } \\
\text { diameter } \\
(\mathrm{cm})\end{array}$ & $\begin{array}{c}\text { Number of } \\
\text { branches per } \\
\text { plant }\end{array}$ & $\begin{array}{c}\text { Number of } \\
\text { leaves per } \\
\text { plant }\end{array}$ & $\begin{array}{c}\text { Leaf area } \\
\left(\mathrm{cm}^{2}\right)\end{array}$ & $\begin{array}{c}\text { Dry matter } \\
\text { per plant } \\
(\mathrm{g})\end{array}$ & $\begin{array}{c}\text { Fruit } \\
\text { setting }(\%)\end{array}$ \\
\hline Blocks & 2 & 3.10 & 0.02 & 0.02 & 0.32 & 0.15 & 0.03 & 0.01 \\
\hline Genotypes & 4 & $8074.82 *$ & $3.23 *$ & $60.98 *$ & $2411.76^{*}$ & $1643.43 *$ & $3.06 *$ & $287.68 *$ \\
\hline Error & 8 & 3.96 & 0.01 & 0.03 & 0.34 & 0.12 & 0.01 & 0.10 \\
\hline
\end{tabular}

* significant at $5 \%$ level

Table (3b): Mean performance, reduction and increasing of the three tomato genotypes (Castle Rock mother population-sensitive genotype, Edkawy tolerant genotype and Castle Rock adapted selected population) grown under saline irrigation during the year 2010.

\begin{tabular}{|c|c|c|c|c|c|c|c|c|c|}
\hline \multirow[b]{2}{*}{ Genotypes } & \multirow{2}{*}{\multicolumn{2}{|c|}{ Treatments }} & \multicolumn{7}{|c|}{ Characteristics } \\
\hline & & & Plant & $\begin{array}{l}\text { Main } \\
\text { stem }\end{array}$ & $\begin{array}{c}\text { Number } \\
\text { of }\end{array}$ & $\begin{array}{l}\text { Number } \\
\text { of leaves }\end{array}$ & Leaf & $\begin{array}{c}\text { Dry } \\
\text { matter }\end{array}$ & Fruit \\
\hline \multirow{4}{*}{$\begin{array}{l}\text { Castle Rock (mother } \\
\text { population - sensitive } \\
\text { genotype) }\end{array}$} & \multirow{2}{*}{$\begin{array}{l}\text { Fresh } \\
\text { water }\end{array}$} & Mean & $122.58 \mathrm{c}$ & $11.25 \mathrm{a}$ & $14.06 \mathrm{~b}$ & $112.47 \mathrm{c}$ & $175.72 \mathrm{c}$ & $5.72 \mathrm{~b}$ & $75.42 \mathrm{a}$ \\
\hline & & $\begin{array}{l}\text { Reduction and } \\
\text { Increasing }(\%)\end{array}$ & -15.40 & -9.69 & 45.68 & 0.73 & -3.80 & -10.35 & -5.19 \\
\hline & \multirow{2}{*}{$\begin{array}{l}\text { Saline } \\
\text { water }\end{array}$} & Mean & $56.54 \mathrm{e}$ & $8.65 \mathrm{e}$ & $11.53 \mathrm{c}$ & $74.69 \mathrm{~d}$ & $128.41 \mathrm{e}$ & $3.86 \mathrm{~d}$ & $51.12 \mathrm{~d}$ \\
\hline & & $\begin{array}{l}\text { Reduction and } \\
\text { Increasing }(\%)\end{array}$ & 83.41 & 17.46 & 77.59 & 51.67 & 31.64 & 32.92 & 39.87 \\
\hline \multirow{4}{*}{$\begin{array}{c}\text { Edkawy (tolerant } \\
\text { genotype) }\end{array}$} & \multirow{2}{*}{$\begin{array}{l}\text { Fresh } \\
\text { water }\end{array}$} & Mean & $182.25 \mathrm{a}$ & $11.02 \mathrm{~b}$ & $11.54 \mathrm{c}$ & $131.55 \mathrm{~b}$ & $187.44 \mathrm{a}$ & $6.53 \mathrm{a}$ & $72.50 \mathrm{~b}$ \\
\hline & & $\begin{array}{l}\text { Reduction and } \\
\text { Increasing }(\%)\end{array}$ & -43.09 & -7.78 & 77.42 & -13.88 & -9.81 & -21.36 & -1.36 \\
\hline & \multirow{2}{*}{$\begin{array}{l}\text { Saline } \\
\text { water }\end{array}$} & Mean & $173.80 \mathrm{~b}$ & $10.71 \mathrm{c}$ & $20.30 \mathrm{a}$ & $151.35 \mathrm{a}$ & $181.65 \mathrm{~b}$ & $5.92 \mathrm{~b}$ & $71.44 \mathrm{c}$ \\
\hline & & $\begin{array}{l}\text { Reduction and } \\
\text { Increasing }(\%)\end{array}$ & -40.33 & -5.14 & 0.91 & -25.14 & -6.93 & -13.37 & 0.09 \\
\hline $\begin{array}{l}\text { Castle Rock (adapted } \\
\text { selected population) }\end{array}$ & \multicolumn{2}{|c|}{ Selected for salinity tolerance } & $103.70 \mathrm{~d}$ & $10.16 \mathrm{~d}$ & $20.48 \mathrm{a}$ & $113.29 \mathrm{c}$ & $169.04 \mathrm{~d}$ & $5.13 \mathrm{c}$ & $71.51 \mathrm{c}$ \\
\hline \multicolumn{3}{|c|}{ LSD } & 3.74 & 0.21 & 0.34 & 1.09 & 0.66 & 0.21 & 0.60 \\
\hline
\end{tabular}

Significant at 5\% level 
Table (4a): Mean square for analysis of variance of genotypes (Castle Rock mother population-sensitive genotype, Edkawy tolerant genotype and Castle Rock adapted selected population) of tomato grown under saline irrigation during the year 2010.

\begin{tabular}{|c|c|c|c|c|c|c|c|c|}
\hline \multirow[b]{2}{*}{$\begin{array}{l}\text { Source of } \\
\text { Variance }\end{array}$} & \multirow[b]{2}{*}{ DF } & \multicolumn{7}{|c|}{ Characteristics } \\
\hline & & $\begin{array}{c}\text { Number of } \\
\text { days to } 50 \% \\
\text { flowering }\end{array}$ & $\begin{array}{l}\text { Number of } \\
\text { days to fruit } \\
\text { ripening }\end{array}$ & $\begin{array}{c}\text { Number of } \\
\text { fruits per plant }\end{array}$ & $\begin{array}{l}\text { Average fruit } \\
\text { weight (g) }\end{array}$ & $\begin{array}{l}\text { Total yield per } \\
\text { plant (g) }\end{array}$ & $\begin{array}{c}\text { Total } \\
\text { chlorophyll } \\
\text { content } \\
\text { (SPAD unit) }\end{array}$ & TSS (\%) \\
\hline Blocks & 2 & 0.04 & 0.06 & 0.07 & 0.03 & 6160.13 & 0.0001 & 0.005 \\
\hline Genotypes & 4 & $158.37 *$ & $409.22 *$ & $149.09 *$ & $2964.38 *$ & $3193430.9 *$ & $0.01 *$ & $3.10^{*}$ \\
\hline Error & 8 & 0.09 & 0.05 & 0.08 & 0.05 & 1277.99 & 0.0001 & 0.007 \\
\hline
\end{tabular}

* significant at $5 \%$ level

Table (4b): Mean performance, reduction and increasing of the three tomato genotypes (Castle Rock mother population-sensitive genotype, Edkawy tolerant genotype and Castle Rock adapted selected population) grown under saline irrigation during the year 2010.

\begin{tabular}{|c|c|c|c|c|c|c|c|c|c|}
\hline \multirow[b]{2}{*}{ Genotypes } & \multirow{2}{*}{\multicolumn{2}{|c|}{ Treatments }} & \multicolumn{7}{|c|}{ Characteristics } \\
\hline & & & $\begin{array}{c}\text { Number of } \\
\text { days to } 50 \% \\
\text { flowering }\end{array}$ & $\begin{array}{l}\text { Number } \\
\text { of days } \\
\text { to fruit } \\
\text { ripening }\end{array}$ & $\begin{array}{c}\text { Number } \\
\text { of fruits } \\
\text { per plant }\end{array}$ & $\begin{array}{l}\text { Average } \\
\text { fruit } \\
\text { weight } \\
\text { (g) } \\
\end{array}$ & $\begin{array}{c}\text { Total } \\
\text { yield per } \\
\text { plant }(\mathrm{g})\end{array}$ & $\begin{array}{c}\text { Total } \\
\text { chlorophyll } \\
\text { content } \\
\text { (SPAD unit) } \\
\end{array}$ & TSS $(\%)$ \\
\hline \multirow{4}{*}{$\begin{array}{c}\text { Castle Rock (mother } \\
\text { population - sensitive } \\
\text { genotype) }\end{array}$} & \multirow[b]{2}{*}{$\begin{array}{l}\text { Fresh } \\
\text { water }\end{array}$} & Mean & $46.74 \mathrm{~d}$ & $100.33 \mathrm{a}$ & $18.50 \mathrm{~b}$ & $86.36 \mathrm{c}$ & $1622.59 \mathrm{c}$ & $0.52 \mathrm{~b}$ & $4.51 \mathrm{~d}$ \\
\hline & & $\begin{array}{l}\text { Reduction and } \\
\text { Increasing }(\%)\end{array}$ & 10.22 & -8.95 & -11.10 & -8.18 & -17.80 & -14.20 & 9.88 \\
\hline & \multirow[b]{2}{*}{$\begin{array}{l}\text { Saline } \\
\text { water }\end{array}$} & Mean & $65.44 \mathrm{a}$ & $69.45 \mathrm{e}$ & $16.22 \mathrm{c}$ & $43.59 \mathrm{e}$ & $789.35 \mathrm{e}$ & $0.36 \mathrm{e}$ & $7.09 \mathrm{a}$ \\
\hline & & $\begin{array}{l}\text { Reduction and } \\
\text { Increasing }(\%)\end{array}$ & -21.27 & 31.51 & 1.34 & 81.89 & 68.95 & 24.16 & -30.18 \\
\hline \multirow{4}{*}{$\begin{array}{c}\text { Edkawy (tolerant } \\
\text { genotype) }\end{array}$} & \multirow{2}{*}{$\begin{array}{l}\text { Fresh } \\
\text { water }\end{array}$} & Mean & $49.36 \mathrm{c}$ & $84.56 \mathrm{c}$ & $24.41 \mathrm{a}$ & $120.52 \mathrm{a}$ & $3082.70 \mathrm{a}$ & $0.56 \mathrm{a}$ & $5.07 \mathrm{c}$ \\
\hline & & $\begin{array}{l}\text { Reduction and } \\
\text { Increasing }(\%)\end{array}$ & 4.36 & 8.01 & -32.62 & -34.20 & -56.73 & -20.74 & -2.34 \\
\hline & \multirow[b]{2}{*}{$\begin{array}{l}\text { Saline } \\
\text { water }\end{array}$} & Mean & $51.67 \mathrm{~b}$ & $79.66 \mathrm{~d}$ & $19.31 \mathrm{~b}$ & $117.22 \mathrm{~b}$ & $2252.04 \mathrm{~b}$ & $0.47 \mathrm{c}$ & $5.86 \mathrm{~b}$ \\
\hline & & $\begin{array}{l}\text { Reduction and } \\
\text { Increasing }(\%)\end{array}$ & -0.29 & 14.66 & -14.82 & -32.35 & -40.77 & -5.49 & -15.45 \\
\hline $\begin{array}{l}\text { Castle Rock (adapted } \\
\text { selected population) }\end{array}$ & \multicolumn{2}{|c|}{ Selected for salinity tolerance } & $51.52 \mathrm{~b}$ & $91.34 \mathrm{~b}$ & $16.44 \mathrm{c}$ & $79.29 \mathrm{~d}$ & $1333.69 \mathrm{~d}$ & $0.44 \mathrm{~d}$ & $4.95 \mathrm{c}$ \\
\hline \multicolumn{3}{|c|}{ LSD } & 0.57 & 0.43 & 0.85 & 0.44 & 67.97 & 0.01 & 0.15 \\
\hline
\end{tabular}

Significant at 5\% level 
Table (5a): Mean square for analysis of variance of genotypes (Castle Rock mother population-sensitive genotype, Edkawy tolerant genotype and Castle Rock adapted selected population) of tomato grown under saline irrigation during the year 2010.

\begin{tabular}{|c|c|c|c|c|c|c|c|c|}
\hline \multirow[b]{2}{*}{$\begin{array}{l}\text { Source of } \\
\text { Variance }\end{array}$} & \multirow[b]{2}{*}{ DF } & \multicolumn{7}{|c|}{ Characteristics } \\
\hline & & $\begin{array}{c}\text { Titrated } \\
\text { acidity }\end{array}$ & $\begin{array}{c}\text { Vitamin } \mathrm{C} \\
\text { content } \\
(\mathrm{mg} / 100 \mathrm{~g})\end{array}$ & $\begin{array}{c}\text { Seed } \\
\text { germination } \\
(\%)\end{array}$ & $\begin{array}{c}\text { Proline } \\
\text { content } \\
(\mathrm{mmol} k g- \\
1 \mathrm{FW})\end{array}$ & Ca (mg/plant) & K (mg/plant) & $\mathrm{Na}(\mathrm{mg} / \mathrm{plant})$ \\
\hline Blocks & 2 & 3.46 & 0.006 & 0.02 & 0.002 & 0.0002 & 0.003 & 0.63 \\
\hline Genotypes & 4 & $0.004 *$ & $0.42 *$ & $961.43 *$ & $7.92 *$ & $3.47 *$ & $5.69 *$ & $7.04 *$ \\
\hline Error & 8 & 0.00001 & 0.004 & 0.35 & 0.001 & 0.0002 & 0.002 & 0.59 \\
\hline
\end{tabular}

* significant at $5 \%$ level

Table (5b): Mean performance, reduction and increasing of the three tomato genotypes (Castle Rock mother population-sensitive genotype, Edkawy tolerant genotype and Castle Rock adapted selected population) grown under saline irrigation during the year 2010.

\begin{tabular}{|c|c|c|c|c|c|c|c|c|c|}
\hline \multirow[b]{2}{*}{ Genotypes } & \multirow{2}{*}{\multicolumn{2}{|c|}{ Treatments }} & \multicolumn{7}{|c|}{ Characteristics } \\
\hline & & & $\begin{array}{l}\text { Titrated } \\
\text { acidity }\end{array}$ & $\begin{array}{l}\text { Vitamin } \mathrm{C} \\
\text { content } \\
(\mathrm{mg} / 100 \mathrm{~g})\end{array}$ & $\begin{array}{c}\text { Seed } \\
\text { germination } \\
(\%)\end{array}$ & $\begin{array}{c}\text { Proline } \\
\text { content } \\
(\mathbf{m m o l} \\
\left.\mathbf{k g}^{-1} \mathbf{F W}\right)\end{array}$ & $\begin{array}{c}\text { Ca } \\
(\mathbf{m g} / \text { plant })\end{array}$ & $\begin{array}{c}\mathbf{K} \\
(\mathbf{m g} / \text { plant })\end{array}$ & $\begin{array}{c}\mathrm{Na}(\mathrm{mg} / \\
\text { plant })\end{array}$ \\
\hline \multirow{4}{*}{$\begin{array}{c}\text { Castle Rock (mother population - } \\
\text { sensitive genotype) }\end{array}$} & \multirow[b]{2}{*}{$\begin{array}{l}\text { Fresh } \\
\text { water }\end{array}$} & Mean & $0.47 \mathrm{e}$ & $16.88 \mathrm{c}$ & $100.00 \mathrm{a}$ & $2.17 \mathrm{e}$ & $3.21 \mathrm{c}$ & $3.88 \mathrm{c}$ & $0.62 \mathrm{~b}$ \\
\hline & & $\begin{array}{l}\text { Reduction and } \\
\text { Increasing }(\%)\end{array}$ & 3.57 & 0.42 & -18.38 & 147.93 & -8.17 & -11.25 & 2.88 \\
\hline & \multirow[b]{2}{*}{$\begin{array}{l}\text { Saline } \\
\text { water }\end{array}$} & Mean & $0.57 \mathrm{a}$ & $17.13 \mathrm{~b}$ & $56.35 \mathrm{~d}$ & $5.96 \mathrm{a}$ & $1.44 \mathrm{e}$ & $1.75 \mathrm{e}$ & $3.64 \mathrm{a}$ \\
\hline & & $\begin{array}{l}\text { Reduction and } \\
\text { Increasing }(\%)\end{array}$ & -13.66 & -1.05 & 44.83 & -9.57 & 104.36 & 95.96 & -82.40 \\
\hline \multirow{4}{*}{ Edkawy (tolerant genotype) } & \multirow[b]{2}{*}{$\begin{array}{l}\text { Fresh } \\
\text { water }\end{array}$} & Mean & $0.51 \mathrm{c}$ & $17.64 \mathrm{a}$ & $100.00 \mathrm{a}$ & $3.51 \mathrm{~d}$ & $4.43 \mathrm{a}$ & $5.34 \mathrm{a}$ & $3.56 \mathrm{a}$ \\
\hline & & $\begin{array}{l}\text { Reduction and } \\
\text { Increasing }(\%)\end{array}$ & -4.45 & -3.92 & -18.38 & 53.51 & -33.46 & -35.55 & -82.00 \\
\hline & \multirow{2}{*}{$\begin{array}{l}\text { Saline } \\
\text { water }\end{array}$} & Mean & $0.53 \mathrm{~b}$ & $17.67 \mathrm{a}$ & $83.38 \mathrm{~b}$ & $5.61 \mathrm{~b}$ & $3.35 \mathrm{~b}$ & $4.75 \mathrm{~b}$ & $2.94 \mathrm{a}$ \\
\hline & & $\begin{array}{l}\text { Reduction and } \\
\text { Increasing }(\%)\end{array}$ & -8.02 & -4.04 & -2.11 & -4.07 & -11.90 & -27.50 & -78.17 \\
\hline $\begin{array}{c}\text { Castle Rock (adapted selected } \\
\text { population) }\end{array}$ & \multicolumn{2}{|c|}{ Selected for salinity tolerance } & $0.49 \mathrm{~d}$ & $16.95 \mathrm{c}$ & $81.61 \mathrm{c}$ & $5.39 \mathrm{c}$ & $2.95 \mathrm{~d}$ & $3.44 \mathrm{~d}$ & $0.64 \mathrm{~b}$ \\
\hline \multicolumn{3}{|c|}{ LSD } & 0.006 & 0.11 & 1.12 & 0.05 & 0.02 & 0.08 & 1.45 \\
\hline
\end{tabular}

Significant at 5\% level 
Table (6a): Mean square for analysis of variance of genotypes (Castle Rock mother population-sensitive genotype, Edkawy tolerant genotype and Castle Rock adapted selected population) of tomato grown under saline irrigation during the year 2010.

\begin{tabular}{|c|c|c|c|c|c|}
\hline Source of Variance & DF & Cortex (\%) & Pith (\%) & $\begin{array}{c}\text { Pith/Cortex } \\
(\boldsymbol{\%})\end{array}$ & $\begin{array}{c}\text { Xylem vessels } \\
\text { diameter }(\boldsymbol{\%})\end{array}$ \\
\hline Blocks & 2 & 0.0002 & 0.0001 & 0.0001 & 6.49 \\
\hline Genotypes & 2 & $243.16^{*}$ & $253.33^{*}$ & $2004.01^{*}$ & $22.86^{*}$ \\
\hline Error & 4 & 0.0001 & 0.001 & 0.0002 & 0.06 \\
\hline
\end{tabular}

* significant at $5 \%$ level

Table (6b): Mean performance, reduction and increasing of the three tomato genotypes (Castle Rock mother population-sensitive genotype, Edkawy tolerant genotype and Castle Rock adapted selected population) grown under saline irrigation during the year 2010.

\begin{tabular}{|c|c|c|c|c|}
\hline Genotypes & $\begin{array}{c}\text { Cortex } \\
(\boldsymbol{\%})\end{array}$ & Pith $(\boldsymbol{\%})$ & $\begin{array}{c}\text { Pith/Cortex } \\
(\%)\end{array}$ & $\begin{array}{c}\text { Xylem } \\
\text { vessels } \\
\text { diameter } \\
(\boldsymbol{\%})\end{array}$ \\
\hline $\begin{array}{c}\text { Castle rock (mother population - sensitive } \\
\text { genotype) }\end{array}$ & $52.03 \mathrm{c}$ & $47.94 \mathrm{a}$ & $92.18 \mathrm{a}$ & $9.91 \mathrm{a}$ \\
\hline Edkawy (tolerant genotype) & $68.24 \mathrm{a}$ & $31.14 \mathrm{c}$ & $45.64 \mathrm{c}$ & $7.36 \mathrm{a}$ \\
\hline Castle rock (adopted selected population) & $66.93 \mathrm{~b}$ & $33.08 \mathrm{~b}$ & $49.43 \mathrm{~b}$ & $4.02 \mathrm{~b}$ \\
\hline LSD & 0.02 & 0.07 & 0.03 & 5.78 \\
\hline
\end{tabular}

Significant at 5\% level

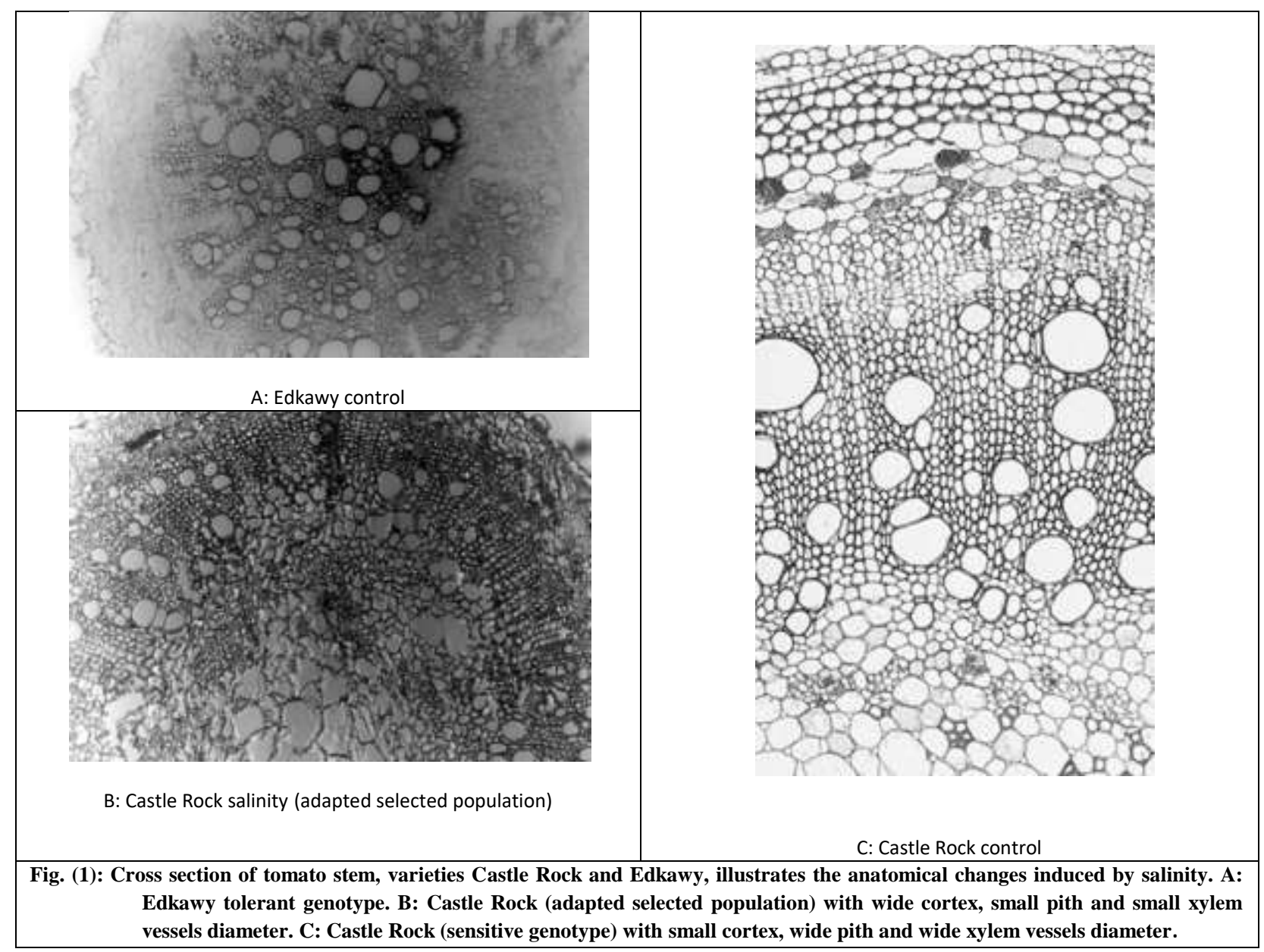


for the characteristics cortex, pith, pith/cortex and xylem vessels diameter. Data in Table (6b) showed the anatomy measurements of main stem of tomato plants grown under saline water stress.The percentage of comparison of cortex to the stem diameter showed significant differences and it was 52.03 for Castle Rock (sensitive genotype - mother population), 68.24 for Edkawy and 66.93 for Castle Rock (adapted selected population $\mathrm{C}_{9}$ ). Comparing the pith to the stem diameter showed significant differences and it was 47.44 for Castle Rock (mother population). 31.14 for Edkawy and 33.08 for Castle Rock $\left(\mathrm{C}_{9}\right)$. In addition, the percentage of comparison of pith to cortex showed significant differences and it was 92.18 for Castle Rock (mother population), 45.64 for Edkawy and 49.43 for Castle Rock (adapted selected population $\mathrm{C}_{9}$ ). While, the percentage of comparing the diameter of xylem vessels to the parenchyma cells showed significant differences and it was 9.91 for Castle Rock (mother population), 7.36 for Edkawy and 4.02 for Castle Rock (adapted selected population $\mathrm{C}_{9}$ ). Similar results were generally reported by Ester et al. (1999) who stated that with increased salinity the cortex and pith of radical increased in width, while the xylem decreased. Also, salinity produced a reduction in the stele diameter of both genotypes because of the decrease in the number and diameter of the xylem vessels (Garzon and Marina, 2011). Figure (1) shows cross section of tomato stem (pith, cortex and xylem), varieties Castle Rock, Edkawy and $\mathrm{C}_{9}$, illustrating the anatomical changes induced by salinity.

As a conclusion, $\mathrm{C}_{9}$ proved tolerant to salinity through adaptation in 9 selecting cycles and it can be reproduced as a new Castle Rock improved line for salinity tolerance.

\section{REFERENCES}

Angers B., Castonguag E. and Massicotte R. (2010). Environmentally induced phenotypes and DNA methylation: how to deal with unpredictable conditions until the next generation and after. Mol. Ecol. 19: 1283 1295.

A.O.A.C. (1980). Official methods of analysis. 12th Ed Association of Official Analysis Chemicals, Washington D.C. USA.

Bates L. S., Waldern R. P. and Teare I. D. (1973). Rapid determination of free proline for water stress studies. Plant and Soil 39: 205 - 207.

Bernstein L., Francois L. E. and Clark R. A. (1974). Interactive effect of salinity and fertility on yield of grains and vegetables. Agron. J. 66: 412 - 421.

Borsani O., Zhu J., Verslues P. E., Sunkars R. and Zhu J. K. (2005). Endogenous siRNAs derived from a pair of natural cis-antisense transcripts regulate salt tolerance in Arabidopsis. Cell. 123: 1279 - 1291.

Chapman H. D. and Pratt P. F. (1978). Methods of analysis for soil, plants and waters. Division of Agric. Univ. California Berkeley USA pp: 309.

Cuartero J., Yeo A. R. and Flowers T. J. (1992). Selection of donors for salt-tolerance in tomato using physiological traits. New Phytologist 121: $63-69$.

Dai J., Xie W., Brady T. L., Gao J. and Voytas D. F. (2007). Phosphorylation regulates integration of the yeast Ty5 retrotransposon into heterochromatin. Mol. Cell 27: 289 - 299.

Deal R. B. and Henikoff S. (2010). A simple method for gene expression and chromatin profiling of individual cell types within a tissue. Dev. Cell 18: 1030 - 1040.

Duncan, D. B. (1955). Multiple range and multiple F tests, Biometrics, 11, 1-42.

Ester C. C., Degano C. A., Toselli M. E. and Catan E. A. (1999). Statistical studies on anatomical modifications in the radical and hypocotyl of cotton induced by $\mathrm{NaCl}$. Biol. Res. 32(4) Santiago.

(http://www.scielo.php?pid=S071697601999000400008\&script=sci arttext).

Flowers T. J., Trake R. F. and Yea A. R. (1977). The mechanism of salt tolerance in halophytes. Ann. Rev. Plant Physiol. 28: 89 - 121.

Francois L. E. and Bernstein L. (1964). Salt tolerance of sunflowers. Agron. J. 65: 38 - 40.

Garzon P. and Marina G. (2011). Effect of $\mathrm{NaCl}$ stress on root and leaf anatomy in two cowpea (Vigna unguiculata L. Walp.) genotypes. Bioagro [online] 23(3): 153 - 160.

Hsiao T. C. (1973). Plant responses to water stress. Ann. Rev. Plant Physiol. 24: 519 - 570.

Johnson, D.W., S.E. Smith, and A.K. Dobrenz. 1992. Genetic and phenotypic relationships in response to $\mathrm{NaCl}$ at different develop-mental stages in alfalfa. Theor. Appl. Genet. 83: $833-$ 838.

Kazim A. A. (1978). Tomato growth and yield as influenced by different levels of saline water application. Mesopotamia J. Agric. 13: 93 100.

Knight H., Trewaves A. J. and Knight M. R. (1997). Calcium signaling in Arabidopsis thalina responding to drought and salinity. 
Plant J. Oxford Black Well Science LTD 12(5): 1067 - 1078 (online abstract).

Kumar S. V. and Wigge P. A. (2010). H2A.ZContaining nucleosomes mediate the thermosensory response in arabidopsis. Cell 140: 136 - 147.

Lahaye P. A. and Epstein E. (1969). Salt toleration by plants: Enhancement with calcium. Science 166: 395 - 396.

Lapina L. P. and Popov B. A. (1970). Effect of sodium chloride on the photosynthetic apparatus of tomatoes. Sovt. Plant Physiol. 17: $477-481$.

Maas E. V. and Hoffman G. J. (1977). Crop salt tolerance: current assessment. J. Irrig. Drain. Div. ASCE 103: 115 - 134.

Madlung A. and Comai L. (2004). The effect of stress on genome regulation and structure. Ann. Bot. 94: 481 - 495.

Mirouze M. and Paszkowski J. (2011). Epigenetics contribution to stress adaptation in plants. Current opinion in plant biology 14: 1 8.

Mizrahi Y. (1982). Effect of salinity on tomato fruit ripening. Plant Physiology. 69: 966 - 970.

Mondal R. C. (1983). Salt tolerance of tomato grown around earthen pitchers. Indian J. Agric. Sci. 53(5): 380 - 382.

Nanawati G. C. and Maliwal G. L. (1974). Note on the effect of salt on growth, mineral nutrition and quality of tomato (Lycopersicon esculentum Mill). Ind. Agric. Sci. 43: 612 614.

Nieman R. H. (1962). Some effects of sodium chloride on growth photosynthesis and respiration of twelve crop plants. Bot. Gaz. 123: 279 - 285.

Nukaya A., Masui A. and Ishida A. (1979). Salt tolerance of tomatoes. J. Japan Soc. Hort. Sci. 48(1): 73- 81.

Perez-Alfocea F., Balibrea M. E., Santa-Cruz A. and Estan M. T. (1996). Agronomical and physiological characterization of salinity tolerance in a commercial tomato hybrid. Plant Soil 180: 251 - 257.

Rajasekaran I. R. and Shanmugavelu K. G. (1981). Effect of different types of soil and quantity of water on tomato. South Indian Hort. 29(2): 95 - 99.

Richard R. A. (1983). Should selection for yield in saline regions be made on saline or non-saline soils?. Euphytica 32, 43: 1 - 438.

Shannon M. C. and Grieve C. M. (1999). Tolerance of vegetable crops to salinity. Sci. Hort. 78: 5 - 38.

Shannon M. C. and Noble C. L. (1990). Genetics approaches for the developing economic salttolerant crops. In"Agricultural salinity Assessment and management" (K.K.Tanji, Ed.), ASCE Manuals and Reports on Engineering practice 71: 161 - 185. ACSE, New York.

Shalhevet J. and Yaron B. (1973). Effect of soil and water salinity on tomato growth. Plant and soil J. 39: 285 - 292.

Sivtser M. V., Ponomarva S. A. and Kuznetsova E. A. (1973). Chlorophyllase activity in tomato leaves under influence of salinization and herbicide. Sov. Plant Physiol. 20: 47 - 48.

Skogley E. O. and Haider S. S. (1969). Effect of sodium and magnesium on barley (Hordium vulgare L.) and tomatoes (Lycopersicon esculentum Mill). Plant and Soil 30(3): 343 359.

Snedecor G. W. and Cochran W. G. (1980). Statistical Methods, 7thed. Iowa State Univ. Press, Iowa, USA.

Stewart G. R. and Lee J. A. (1974). The role of proline accumulation in halophytes. Planta 120: 279 - 289.

Tsenov E. I., Strogonov B. P. and Kabanov V. U. (1973). Effect of sodium chloride on content and sysnthesis nuclic acid in tomato tissues. Sov. Plant Physiol. 20: 40 - 41.

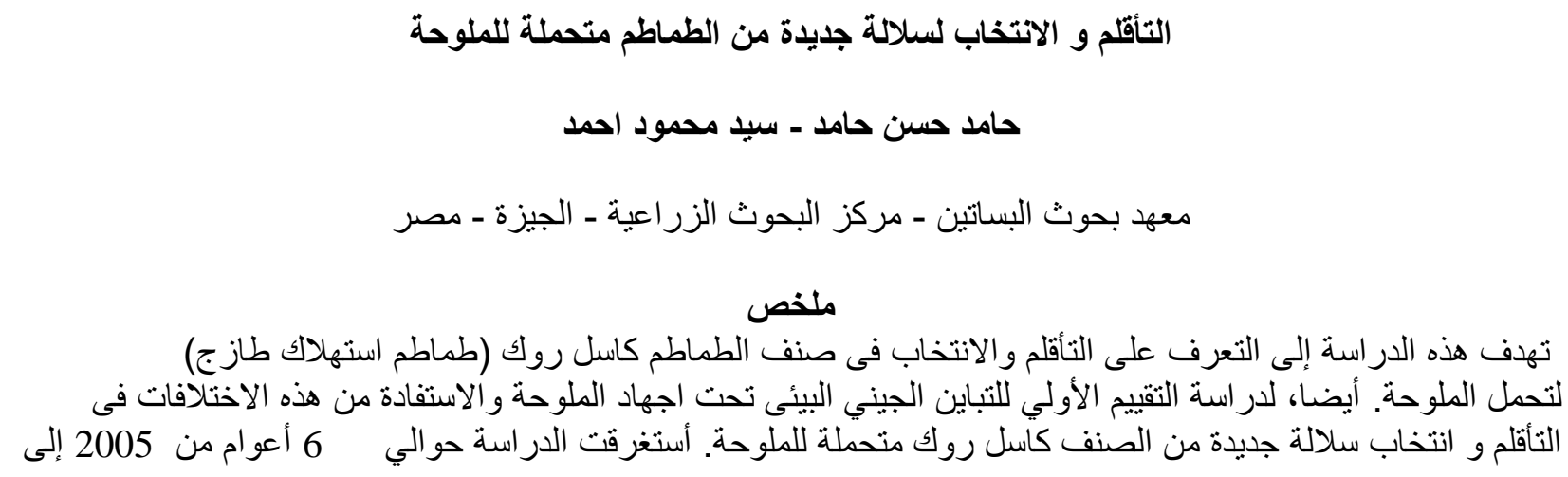




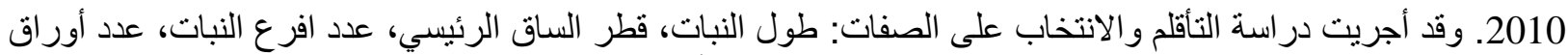

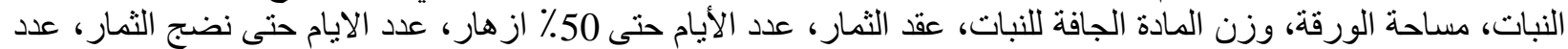

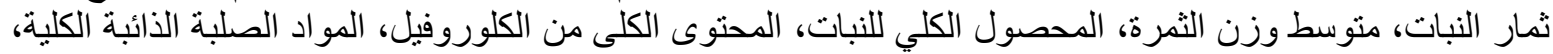

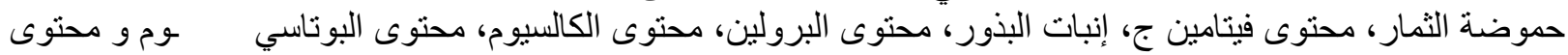

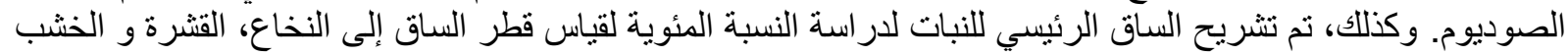

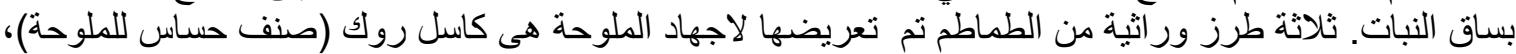

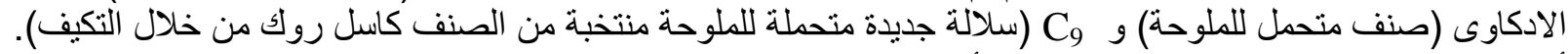

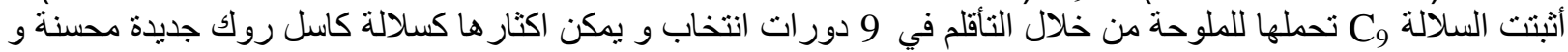
متحملة للملوحة. المجلة العلمية لكلية الزراعة - جامعة القاهرة ـ المجلا (64) العدد الأول (يناير2013):46-58. 